Cornell Law Library

Scholarship@Cornell Law: A Digital Repository

Cornell Law Faculty Publications

Faculty Scholarship

$7-1-2008$

\title{
The Anti-Network: Private Global Governance, Legal Knowledge, and the Legitimacy of the State
}

Annelise Riles

Cornell_Law School, ar254@cornell.edu

Follow this and additional works at: http://scholarship.law.cornell.edu/facpub

Part of the Comparative and Foreign Law Commons

\section{Recommended Citation}

Riles, Annelise, "The Anti-Network: Private Global Governance, Legal Knowledge, and the Legitimacy of the State" (2008). Cornell Law Faculty Publications. Paper 36.

http://scholarship.law.cornell.edu/facpub/36

This Article is brought to you for free and open access by the Faculty Scholarship at Scholarship@Cornell Law: A Digital Repository. It has been accepted for inclusion in Cornell Law Faculty Publications by an authorized administrator of Scholarship@Cornell Law: A Digital Repository. For more information, please contact jmp8@cornell.edu. 


\section{The Anti-Network: Private Global Governance, Legal Knowledge, and the Legitimacy of the State}

Global private law has become the source of both anxiety and euphoria. Inherent in this fascination is the assumption that global private law threatens the legitimacy of the state by taking over its functions through new techniques of governance. In this article, I build upon research in one arena of global private governance, the production of legal documentation for the global swap markets, to challenge the most prominent assumptions about private law beyond the state. I argue that rather than focusing on how global private law is or is not an artifact of state power, a body of private norms, or a coherent legal system, we should view global private law as a set of institutions, actors, doctrines, ideas, documents, that is, as a specialized set of "knowledge practices." Viewed from this perspective, global private law is not a radical departure from state law, but really more of the same. Ultimately, I suggest that the "threat," if any, of global private law for the state lies instead in the way it replicates the work of the state in practical, mundane, and routine ways.

\section{INTRODUCTION}

In the late 1990s, a visitor to a Japanese derivatives trading floor encountered a large open room full of metal desks and computer screens. At most of these desks, traders hunched over their computers or shouted into their telephones. As the traders at their computers entered into a swap with traders at another bank in New York or London, they scribbled the details of the trade onto a form, then tossed it into a basket at the edge of their desk.

* Jack G. Clarke Professor of Far East Legal Studies, Cornell Law School. This article draws upon ethnographic research conducted from 1996 to 2001 in Tokyo and the United States for a forthcoming book, Collateral Knowledge: Legal Reason in the Global Markets. For careful criticism that substantially improved the piece, I am grateful to Anna Gelpern, Ralf Michaels, Hiro Miyazaki, Jeff Rachlinski, Mathias Reimann, and audiences at the Private Law Beyond the State Conference, Hamburg, the Communicating Legitimacy Conference, University of Chicago, and the 2007 Annual Meeting of the Law and Society Association, Berlin. I thank Leticia Barrera for research assistance. 
But a few desks to one side were stacked high with documents and large quantities of paper. Periodically, the people working behind the stacks of documents collected these forms and returned to their desks. Within eyesight of the traders and the manager of the derivatives team, these "documentation people" "papered the trades" as people said. The employees at these desks produced confirmation agreements and sent these to their counterparts at the other bank.

These confirmation documents adhered to a standard format, such that the documentation person's principal task was simply to complete the form, fax it, receive a similar fax from his or her counterpart at the other bank, and file it away. Occasionally, this person might discover discrepancies-misunderstandings between the two parties over the terms, for example-and then would refer these back to the traders to resolve or contact their counterparts at the other bank to resolve the dispute.

Global private law is now the source of both anxiety and euphoria. So-called global private law regimes-private in the sense that they do not rely primarily on the legitimacy or the coercive power of the state for their authority-now fascinate legal theorists for whom the authority, legitimacy, and power of law has long been tethered to the state. ${ }^{1}$ But much of the conversation about global private law proceeds at some distance from the concrete moments, practices, and individuals that constitute global private governance regimes.

In this article, I build upon research in one arena of global private law, the production of legal documentation for the global swap markets, to challenge the way both utopic and dystopic accounts describe private law beyond the state. I argue that these accounts stand on a set of anthropological assumptions or claims-assertions about what this private law actually is, from an insider's point of view, about how it is interpreted and experienced "in the real world"which for the most part go unexamined, untheorized, and undefended empirically. This matters because they also turn out to be, at the very least, seriously incomplete.

In particular, I want to challenge, or at least complicate, three views of the source of private law's legitimacy that figure prominently in both defenses and critiques of private law: the view that law is an artifact of state power, ${ }^{2}$ the view that law enshrines a set of norms ${ }^{3}$ and the view that law is a coherent system of one kind or

1. See, e.g., Rodney Bruce Hall \& Thomas J. Bierssteker, The Emergence of Private Authority in Global Governance (2002). (1927).

2. See, e.g., Morris R. Cohen, Property and Sovereignty, 13 CoRnell L.Q. 8

3. See, e.g., Hans Kelsen, Pure Theory of Law (Max Knight transl., 2d rev. \& enlarged German ed. 1967); Herbert L. A. Hart, The Concept of Law (1961). 
another. ${ }^{4}$ In contrast, I will suggest that if one approaches these debates from the standpoint of the deceptively naïve question, "what is collateral, really, in the derivatives markets?" one begins to grasp a view of law as something very different from a body of norms. Global private law is also, I want to suggest, a set of routinized but highly compartmentalized knowledge practices. I will shorthand this description of global private law as the Anti-Network in order to contrast it to celebrations of global private law as an artifact of global networks of various kinds. ${ }^{5}$ Debates about the sources of private law's legitimacy, I will suggest, need to be redirected to contend with a more accurate picture of global private law.

My alternative description of private law beyond the state has implications for the question of how and to what extent global private law threatens the legitimacy of the state. Up to now, it has been taken for granted by most proponents and critics alike that global private law is something analogous to, but ultimately different from state law. 6 That is, it has been assumed that global private law threatens the legitimacy of the state by taking over the functions of the state through other (ostensibly more efficient, more accepted, or more normatively defensible) means. In contrast, I argue that to the extent that global private law poses a threat to the state it is not because private law is somehow functionally analogous to, but qualitatively different from, state law. Rather, if one understands private law beyond the state, as I do, as a set of institutions, actors, doctrines, ideas, material documents-of "knowledge practices"7-one begins to see remarkable similarities between the technical workings of global private law and the nature of "state work." From this perspective, the "threat," if any, of global private law inheres instead in

4. See, e.g., Kelsen, supra note 3; René David \& John E.C. Brierley, Major Legal Systems in the World Today (1978). For a critique of this view of law, see James Gordley, Comparative Law and Legal History, in OXford HaNDBOoK OF ComPARATIVE LAw 753 (Mathias Reimann \& Reinhard Zimmerman eds., 2006).

5. See, e.g., Rules and Networks: The Legal Culture of Global Business Transactions (Richard P. Appelbaum, William L.F. Felstiner \& Volkmar Gessner eds., 2001); Sol Picciotto, Networks in International Economic Integration: Fragmented States and the Dilemmas of Neo-Liberalism, 17 Nw. J. INT'L L. \& Bus. 1014 (1996-97). Analogous arguments are made about public international law. See, e.g., Margaret E. Keck \& Kathryn Sikkink, Activists Beyond Borders: Advocacy NetWORKS In InTERnational Politics (1998).

6. For an account of how global private law might be analogous to state law, see David V. Snyder, Private Lawmaking, 64 OHio ST. L.J. 371 (2003). As Ralf Michaels and Nils Jansen make plain, this assumption is more prevalent in the American literature on private law. In Germany, in contrast, a different conception of both private law and of the state would hold that private law is in fact a part of state law. See Ralf Michaels \& Nils Jansen, Private Law Beyond the State? Europeanization, Globalization, Privatization, 54 AM. J. CoMP. L. 843 (2006).

7. See Annelise Riles, A New Agenda for the Cultural Study of Law: Taking on the Technicalities, 53 Buff. L. Rev. 973 (2005); AnNelise Riles, Collateral KnowlEDGE (2007) (unpublisted manuscript, on file with the author). 
the way it replicates and hence supersedes the state in practical, mundane, routine ways.

In the sections that follow, I consider how a close-up description of some moments in global private law-making, like the one with which I began, might cause us to rethink the three most prominent assumptions about global private law. I then conclude with some implications for how to think about whether and how global private law might be "beyond the state."

\section{Rethinking Private Law as an Artifact of State Power}

In order to evaluate and specify the claims often made about global private law, I turn to empirical observations conducted through participant observation in one arena of private governance, the self-regulation of the global swap markets through the posting of collateral in Tokyo. The privately negotiated derivative markets are intended to be the most private of markets. Unlike the futures and options markets, swaps are not traded over an organized exchange. The parties to a swap make their own rules, tailor their own contracts, and above all, privately bear the full risk that one or another will not perform their obligations rather than placing their confidence in the exchange as an intermediary. ${ }^{8}$ Since securities regulation law was designed to regulate on-exchange activity, much swap trading falls between the regulatory cracks. ${ }^{9}$ When disputes arise,

8. Ronit and Schneider usefully distinguish between private legal authority which is delegated to the private law-making institution by a state, and private legal authority which is autonomously claimed or built by non-state forces. Karsten Ronit \& Volker Schneider, Private Organizations and Their Contribution to Problem-Solving in the Global Arena, in Private Organizations in Global Politics 1, 23 (Karsten Ronit \&Volker Schneider eds., 2000). However, they also overstate the distinction where they fail to consider how the actions of private actors exercising regulatory authority outside state action, may in fact constitute a delegation of authority from the state.

9. At present, in the absence of extensive case law or regulatory actions by the U.S. Securities and Exchange Commission or the Commodity Futures Trading Commission, there is some uncertainty about the implications of American securities laws for the derivatives markets. The statutory language (concerning such issues as fraud and insider trading) of the American securities laws is very broadly stated, and designed with the kinds of fraud in mind that would apply to manipulation of on-exchange trading. The case law, likewise, is closely linked to on-exchange transactions. Although solid doctrinal arguments for the application of portions of the securities laws to certain entities in the swap markets could be made, to date, neither the SEC and the CFTC have shown a strong inclination to develop those arguments.

Nevertheless, the trading activities of swap partners are subject to various forms of regulation, by virtue of these players' nature as regulated institutions. As Hal Scott points out, however, this can lead to irregular levels of regulation in a market that includes a variety of parties, including banks, securities firms, corporations, hedge funds, governments and individuals:

As a formal matter, the derivatives activities of banks in the United States are highly regulated by bank supervisors. This regulation involves detailed examination of their activities as well as the capital requirements discussed below ... . However, there is no regulatory framework for supervision of the 
therefore, often parties' only option is to bring a lawsuit in a domestic court under ordinary common or civil law claims such as breach of contract, or fraud. ${ }^{10}$ Since this is often impractical, the effect is that the parties have relatively little recourse to the state to resolve their internal problems. And this is precisely the appeal of these markets, from participants' point of view.

When the documentation people described above were not at work completing and dispatching confirmation forms, they huddled behind piles of binders full of printed forms, dictionaries and pencils in hand, talking on the telephone with colleagues at other banks as they worked through the blanks in the forms. The most common printed form was a standardized "master agreement"11 that provides the legal framework for all individual swap transactions between any two banks. It defines key practices, rights and obligations, such as the use of confirmation documents, or the procedures for cashing out obligations in the event of the financial failure of one of the parties.

The form had been produced by representatives of important players in the swap markets, working together under the auspices of the International Swaps and Derivatives Association (ISDA). Founded in 1985, ISDA is a private organization of more than 750 over-the-counter derivatives "dealers"-banks and securities firms that are repeat players ("dealers") in the privately negotiated derivatives industry, the market for derivatives that are not traded through an organized exchange. ${ }^{12}$ The master agreement is one of ISDA's early and lasting achievements, and the production of this and other standardized agreements is one of the principal functions of the association. ${ }^{13}$

derivatives activities of securities firms by the SEC or the Commodity Futures Trading Corporation (CFTC). Securities firms are not generally regulated for safety and soundness except through capital requirements, and unregistered affiliates of such firms dealing in swaps have not even been subject to capital requirements, until the SEC's proposal in 2003 in response to the EU's Conglomerates Directive.

Hal S. Scott, International Finance: Transactions, Policy, and Regulation 640 (2006).

Banks are subject to capitalization requirements under the terms of the Bank for International Settlements, an international organization of bank regulators. There are also disclosure and accounting rules that apply to public companies.

10. Most of the large lawsuits by users of derivatives against dealers have been brought on common law and statutory grounds such as fraud and failure to disclose material information, or have tested on the argument that the end user plaintiff was prohibited from engaging in derivatives trading. ScoTt, supra note 9, at 663. See also Frank Partnoy, The Shifting Contours of Global Derivatives Regulation 22 U. PA. J. INT'L. ECON. L. 421 (2001).

11. International Swaps and Derivatives Association, Inc., Master Agreement (2002).

12. See International Swaps and Derivatives Association, Inc., Membership, http://www.isda.org/membership/ (last visited Dec. 17, 2006).

13. See Joshua Cohn, ISDA Master Agreements: 19921987 Versions ComPARED 2-13 (1992); INTERNational SwaPs aNd Derivatives Assoclation, InC., User's 
Although the document standardizes many aspects of the practice of swap trading, it also allows for a certain amount of flexibility and adaptation by its users through a "schedule" at the end in which the parties can specify some of the details to their particular relationship, such as how payments are to be made. Hence the task of the documentation people was to tailor the agreement to the needs of the bank and its counterparties by filling in the blanks in the form.

At first blush, it may seem odd to focus on this kind of legal work as an example of global private law. It has become commonplace in sociolegal studies to focus instead on the "creative capacities of lawyers"14-in bringing clients together, inventing innovative solutions to business problems, pushing the development of law, and hence shaping the character of society. But the rote and repetitive work of the documentation people, defined by its precision and attention to detail rather than its creativity, and by its distance from legal theory, points to another, too little acknowledged modality of legal work.

All this mundane activity is relevant to the nature of global private law and to the question of the extent to which it operates outside or beyond the state in two senses. First, the ISDA master agreement is the work of a powerful global private organization of the kind that is now at the center of many debates about global private law. ${ }^{15} \mathrm{Sec}-$ ond, within the field of global derivatives trading, collateralization is a legal technology that is paradigmatic of global private law solutions. Although collateral is an artifact of multiple kinds of national law, ${ }^{16}$ it is also a device for running an end-game around certain aspects of national law. In the event of bankruptcy, collateral gives swap counterparties a mechanism other than the priority system of national bankruptcy laws with its concerns for the interests of third

Guide to the 1992 ISDA Master Agreemen's (1993); The ISDA Collateral Documentation Working Group, International Swaps and Derivatives Association, Instructions to External Counsel form 2 (1999); Christian A. Johnson, Overthe-Counter Derivatives Documentation (2000). ISDA produced the first version of its Master Agreement in 1987. It revised it in 1992 to account for new kinds of derivatives products developed in the intervening years.

14. Maureen E. Cain \& Christine Harrington, Introduction, in LAwYERS IN A Postmodern World: Translation and Transgression 1 (Maureen E. Cain \& Christine Harrington eds., 1994).

15. See Kevin E. Davis, The Role of Nonprofits in the Production of Boilerplate, 104 MiCH. L. REv. 1075 (2006).

16. The rights of the collateral holder are a matter of national property, contract and commercial law, and the requirements for giving and taking collateral (for creating a security interest in US parlance), are defined by and vary according to, the terms of local statutory and common law. In the common and civil law traditions alike, collateral has long been recognized as a special kind of property right. Collateral is a species of ius in re aliena in Roman Law, rights in others' property, which "impose restrictions on the exercise of the rights of ownership by the owner." ADOLF Berger, Encyclopedic Dictionary of Roman Law 27 (1953); Roscoe Pound, Juris. PRUDENCE 185 (1959). In the individual states of the United States collateral is now also understood as a species of commercial law enshrined and protected by statuteby the Uniform Commercial Code as adopted in each state. 
parties through which to resolve disputes. ${ }^{17}$ Collateral is a self-help mechanism: in many jurisdictions the collateral holder may simply keep the collateral to satisfy the debtor's obligations, without going to court. ${ }^{18}$ Collateral emerges as a solution to a practical problem of transnational governance, therefore. The problem is that the terms of the national bankruptcy laws of many of the countries in which derivatives trading occurs and the way these are interpreted and enforced by national bankruptcy judges do not always suit the global derivatives industry because they do not prioritize their claims ahead of others. ${ }^{19}$

But collateral has many other advantages other than protection against bankruptcy. For example, it becomes a vehicle for the parties to privately steer their relationship through other turbulent waters: the ISDA Master Agreement lists a number of "events" short of bankruptcy that trigger the collateral holder's right to close out its positions and use the collateral to satisfy any residual debts. ${ }^{20}$ In this respect, collateral shares certain functional features with other private commercial practices such as the uses of barter in international trade, ${ }^{21}$ or the rules commercial banks have developed for letter of

17. This fact is generally celebrated in the practitioner literature for derivatives lawyers and by some scholars of derivatives law and decried by some scholars of bankruptcy law. See, e.g., Kimberly Summe, The European Union's Collateral Reform Initiatives, 22 (6) COMPANY LAw 186 (2001). For criticisms from bankruptcy law scholars, see Franklin R. Edwards \& Edward R. Morrison, Derivatives and the Bankruptcy Code: Why the Special Treatment? 22 YALE J. ON REG. 92 (2005); Ronald J. Mann, Bankruptcy and the Entitlement of the Government: Whose Money is it Anyway?, 70 N.Y.U. L. Rev. 993 (1995); Ronald J. Mann, Explaining the Pattern of Secured Credit, 110 HARv. L. REv. 625 (1997); Elizabeth Warren \& Jay L. Westbrook, Contracting Out of Bankruptcy: An Empirical Intervention, 118 HARv. L. REv. 1197 (2005).

18. Perhaps this is why a recent study of creditor rights in twelve transition economies found that the protections afforded creditors by collateral law correlate better than the protections afforded creditors by bankruptcy law with increased levels of lending. See Rainier Haselmann, Katharina Pistor \& Vikrant Vig, How Law Affects Lending, 285 Columbia Law and Economics Working Paper (2006), available at SSRN: http://ssrn.com/abstract=846665.

19. Lucian Arye Bebchuk \& Jesse M. Fried, The Uneasy Case for the Priority of Secured Claims in Bankruptcy, 105 YaLE L. J. 857 (1996). As Carruthers, Babb and Halliday show, bankruptcy law reform is part of the standard package of neoliberal reforms instituted by countries around the world since the early $1990 \mathrm{~s}$. Bruce G. Carruthers, Sarah L. Babb \& Terence C. Halliday, Institutionalizing Markets, or the Market for Institutions? Central Banks, Bankruptcy Law, and the Globalization of Financial Markets, in The Rise of Neoliberalism and Institutional Analysis 94, 105 (John L. Campbell \& Ove Kaj Pedersen eds., 2001). These reforms in most cases actually run counter to other neo-liberal reforms because by favoring reorganization over liquidation they continue to protect debtors from creditors and to preserve a sphere of national regulation from the reach of global capital. Carruthers, Babb \& Halliday, supra, at 116-18.

20. ISDA Master Agreement clause on bankruptcy.

21. See Dalia Marin \& Monika Schnitzer, Contracts in Trade and Transition: THE RESURGENCE OF BARTER (2002). My thanks to Jing Leng for bringing this analogy to my attention. 
credit practices. ${ }^{22}$ We might say that collateral becomes, in a practical sense, a kind of private constitution for the parties' ongoing relationship. ${ }^{23}$

For some, claims about the global production of private law of this kind become an urgent object of critique. These commentators seek to show that the "technical" quality of global private law is in fact highly politicized. ${ }^{24}$ They renew and expand longstanding critiques of the public-private distinction in domestic law to demonstrate that global private law is always dependent upon state legal institutions for enforcement. ${ }^{25}$

It is certainly true, as these critics assert, that collateral is an artifact of multiple kinds of publicly created law. ${ }^{26}$ Collateral transactions in the privately traded derivatives markets raise particular problems of interface between multiple national legal systems, including problems of determining what law applies to any particular collateral transaction. ${ }^{27}$ The answers to these questions are murky, ${ }^{28}$

22. Janet K. Levit, A Bottom-up Approach to International Lawmaking: The Tale of Three Trade Finance Instruments, 30 YALE J. INT'L L. 125 (2005).

23. See Annelise Riles, Collateral Relations: Property Relations in the Near Future (unpublished manuscript, on file with the author). See also Mann, supra note 17. Note that collateral does serve one important function, which is not "private" in nature: the Bank for International Settlements capitalization requirements for banks allows credit counterparties for collateralization in calculating capital adequacy requirements. Hence collateralizing transactions lowers capital adequacy requirements and makes trading cheaper. See generally, BASEL CoMmiTTEe on BANKING Supervision, A New Capital Adequacy Framework (1999).

24. "Transnational merchant law, which is generally and mistakenly regarded in purely technical, functional, and 'apolitical' terms, is . . . a central and crucial mediator of domestic and global political/legal orders in that it enables the extraterritorial application of national laws as well as the domestic application of transnational commercial law." Claire A. Cutler, Private Power and Global Authority: Transnational Merchant Law in the Global Political Economy 4 (2003).

25. These critics point out that the architecture of the transnational global private law regime is founded on the national private law of property and contract in particular. Caroline Bradley emphasizes, for example, that contracts rely upon the mechanisms of the state for enforcement and transform these in turn, such that the "apparent sharp distinction between governmental and self-regulation soon breaks down." Caroline Bradley, Private International Law-making for the Financial Markets, 29 FordHAM INT'L L.J. 127, 128 (2005).

26. See supra note 16 and accompanying text.

27. Randall D. Guynn, Modernizing Securities Ownership, Transfer and Pledging Law: A Discussion Paper on the Need For International Harmonization with Responding Comments by Professor James Steven Rogers (USA), Professor Kazuaki Sono (Japan) and Dr. Jürgen Than (Germany), 1996 I.B.A. CAPITAL MaRkETs Forum, Sec. on Bus. L.; Randal D. Guynn \& Margaret Tahyar, The Importance of Choice of Law and Finality to PvP, Netting and Collateral Arrangements, 4(2) J. Fin. REG. \& ComPlince 170 (1996).

Conflict of laws issues occupied the attention of ISDA legal staff I observed as much as any other area of law. See RiLes, supra note 7. Foreign holders of collateral feared that in the event of the bankruptcy of a counterparty in Tokyo, for example, Japanese bankruptcy courts might choose to apply Japanese law and they might not recognize the priority of the collateral transaction over other creditors' claims. See Hasan-ho, Law No. 71 of 1922 . According to Hattori and Henderson, Japanese bankruptcy law has a strongly territorialist orientation and Japanese courts therefore can adjudicate 
doctrinally arcane, and just as variable, from jurisdiction to jurisdiction, as is the law of collateral itself. ${ }^{29}$ Robert Wai terms these thorny

only those assets within Japanese territory. Dan F. Henderson \& TAKaAkI HatTori, Civil Procedure In JAPAN, \$11-27, \$11-28, \$11-29 (1983). However, case law diverges from this "to the point where Japanese bankruptcy proceedings affect foreign assets, and foreign bankruptcy proceedings affect assets in Japan." HENDERson \& HaTTORI, supra, § 11-28.

28. The transnational nature of collateral transactions goes beyond the mere (but important) fact that the parties to a swap are often incorporated in different jurisdictions. Collateral may be posted in different currencies, or in the form of government bonds issued by different governments. The collateral usually is held with intermediaries often incorporated in yet other jurisdictions, with places of business in still other locales. These intermediaries book the collateral in computerized ledgers maintained on servers that may be located yet elsewhere in the world. And when, as is permitted under the law of some countries, the pledgee (the party which receives the collateral) "repledges" the collateral to yet another party to satisfy its own obligations, which then repledges it again, one gets a picture of a constant global movement of collateral in and out of accounts in many jurisdictions.

29. Patrick J. Borchers, Choice of Law Relative to Security Interests and Other Liens in International Bankruptcies, 46 AM. J. CoMP. L. 165 (1998).

On questions relating to the validity of the collateral, some jurisdictions, following classical private international law rules, look to the law of the place where the securities are held. But doctrine in this area developed to deal with tangible forms of property, such as paper securities. Where "collateral" is in actuality a set of numbers in a computerized account, or in multiple accounts, maintained by multiple intermediaries, the question of where it "is" for the purpose of this analysis is almost metaphysically unanswerable. One resolution adopted by some jurisdictions (including the U.S. in the wake of recent revisions to the UCC, as concerns certain issues) is to look to the law of the place where the intermediary whose account the collateral is held with is located. Richard Potok, Legal Certainty for Securities Held as Collateral, 18 InT'L FIN. L. REv. 12 (1999). Recent revisions to Article 8 and 9 specifically take the UCC global by addressing questions of choice of law and tailoring the terms to the character of cross-border transactions:

The local law of the securities intermediary's jurisdiction, as specified in subsection (e), governs:

(1) acquisition of a security entitlement from the securities intermediary;

(2) the rights and duties of the securities intermediary and entitlement holder arising out of a security entitlement;

(3) whether the securities intermediary owes any duties to an adverse claimant to a security entitlement; and

(4) whether an adverse claim can be asserted against a person who acquires a security entitlement from the securities intermediary or a person who purchases a security entitlement or interest therein from an entitlement holder. UCC $\$$ 8-110 (b). See also U.C.C. art. 9 (1999); 3 U.L.A. 9, 9 (Supp. 1999) (effective July 1, 2001). In some respects, at least, the European Union follows a similar approach. See, Parliament and Council Directive 2002/47 on financial collateral arrangements art. 8, O.J. (L 168) 4344.

Another approach (adopted in the U.S. by UCC Article 9 with respect to certain issues relating to the validity of the security interest) is to look to the law of the location of the debtor. Ryan E. Bull, Operation of the New Article 9 Choice of Law Regime in an International Context, 78 TEx. L. Rev. 679 (2000). For many (but not all) legal issues surrounding validity, Japanese courts look to the law of the place where the securities were issued. Hideki Kanda, Japan, in Cross Border Collateral: Legal RisK and THE Conflict of Law 366 (Richard Potok ed., 2002). And this says nothing about what law would govern the question of the priority of the collateral holder's claim, in the event of bankruptcy. The question of how different national courts with jurisdiction over the assets of a bankrupt company with transnational contacts should coordi- 
doctrinal problems "touchdown points" in the relationship between global private governance and national law-points at which the efforts of private organizations such as ISDA to achieve "lift-off" from national regimes comes to rest on national law itself. ${ }^{30}$

But this critique of global private governance is certainly not news to the proponents of global private governance institutions like ISDA. The legal experts with whom I worked understood full well that the private law of collateral is always only a partial global solution to their local legal problems. ${ }^{31}$ They were intimately aware, for example, that the terms of any collateral agreement must satisfy national requirements for creating a valid and enforceable security interest in order for the lender to be able to use the collateral, or again, that national bankruptcy law must recognize the primacy of the interest of "secured creditors" over other creditors if the collateral agreement is to have force once the debtor has declared bankruptcy. In fact, it was at these junctures that the legal actors I studied labored-these constraints created the legal work for them to do.

For example, where the terms in ISDA's standardized documents conflict with the norms enshrined in national statutory or judgemade law, ISDA actively works to supplant or change the latter so that it conforms to the former. ISDA hires local lawyers to investigate discrepancies between the terms of ISDA documents and national law, and where necessary, to lobby national governments to change national law to either conform to the terms of the Master Agreement

nate, and when they should defer to the law of another jurisdiction, remains very much unresolved. Hannah L. Buxbaum, Rethinking International Insolvency: The Neglected Role of Choice-of-Law Rules and Theory, 36 STAN. J. INT'L L. 23 (2000).

30. See Robert Wai, Transnational Liftoff and Juridical Touchdown: The Regulatory Function of Private International Law in an Era of Globalization, 40 CoLuM. J. Transnat'L L. 209 (2002), Wai adapts the legal realist and critical legal studies insight that technical legal issues (such as here, which law should apply) are always already forms of political compromise and hence open for reopening as tools of political change. See Roberto Mangabeira Unger, FalSE NECESSITY-ANTI-NECESSITARIan SOCIAL THEORY IN THE SERVICE OF RADICAL DEMOCRACY (2001). Wai and others suggest that Private International Law is uniquely suited to address the particular problems posed by the global private law such as overlapping legal regimes, or "regulatory gaps" where no particular state regulates a certain practice. Id.

\section{As one such lawyer writes,}

The ISDA Agreement should not be perceived as a law unto itself. The fundamental legal principles of contract law, company law, trust law, the law of torts and the law of insolvency, etc., still apply, as appropriate, in circumstances where an ISDA Agreement becomes the subject-matter of litigation. From a business standpoint, the significance of national boundaries has decreased considerably in the last decade. However, it remains the case that, from a legal standpoint, national boundaries continue to be very important, not least in the context of insolvency.

Agnes Foy, The ISDA Master Agreement-Managing Legal Risk: Jurisdictions and Counter-parties, 6 Com. L. Prac.104 (1999). 
or explicitly declare the ISDA documents enforceable. ${ }^{32}$ Partly at the urging of ISDA, and with active input from the organization, several transnational bodies are busy creating substantive legal rules concerning collateral that would apply in multiple jurisdictions and supersede national law. ISDA has pressed for the creation of a treatyperhaps the ultimate example of global state law-that would mandate that national judges respect private parties' right to choose whatever law they wish to have applied to their collateral agreements. ${ }^{33}$ In response to lobbying from ISDA, ${ }^{34}$ the European Union has adopted a Directive on Financial Collateral Arrangements defining how security interests are to be created in EU Member States, and the rights of holders of collateral. ${ }^{35}$ And ISDA has also worked with UNIDROIT, the international body devoted to unifying private law globally, ${ }^{36}$ on a Convention on Harmonised Substantive Rules re-

32. In the United States, intensive lobbying on the part of ISDA has resulted in important revisions of New York state law, the UCC, and the national bankruptcy law, and has averted other proposed regulation opposed by ISDA. The European Union also has responded to ISDA lobbying by producing a directive on collateral supported by ISDA. In Tokyo, likewise, ISDA has an elaborate system of committees in place to address legal reforms as well as high-level contacts in all branches of the Japanese bureaucracy. The representatives of even the foreign banks at ISDA Tokyo meetings are almost exclusively Japanese employees of these foreign banks, graduates of top universities with connections to former teachers and classmates in the bureaucracy and on the bench.

33. On December 13, 2002, the Hague Conference on Private International Law adopted a Convention on the Law Applicable to Certain Rights in Respect of Securities Held with an Intermediary, available at http://www.hcch.net/index_en.php?act= conventions.text\&cid=72. This convention, a product of intensive lobbying by ISDA and other global commercial groups, affirms that if the agreement between the intermediary and the custodian of the security specifies which law should apply, that law applies as long as it bears a reasonable relationship to the transaction. The first order principle of the convention is the freedom of the account holder and intermediary (but not the pledgor and pledgee) to choose the applicable law by contract. Groups such as ISDA participated actively in the drafting of the convention. The Hague Conference official with primary responsibility for its drafting defends this freedom of contract principle on grounds that states have an interest in economic development, and in supporting "certainty in the marketplace promoted by the Convention. This is not a case of private versus public interest. The Convention itself represents a clear decision by the state that the public interest resides in enforcement of the Convention's rule. "Harry C. Sigman \& Christophe Bernasconi, Myths about the Hague Convention Debunked, INT'L FIN. L. Rev., Nov. 2005, at 31. The convention was concluded July 5, 2006 , but it has not yet come into force. Even if the question of which law governs the collateral agreement is ultimately settled by treaty, this will not resolve the question of the relationship between the law of collateral and national bankruptcy law: it will not preclude a Japanese bankruptcy court for example from recognizing the collateral as valid under New York law as specified by the CSA, but then applying Japanese bankruptcy law to the question of whether the collateral holder should be able to keep the collateral after a bankruptcy filing.

34. James Coiley, New Protections for Cross-Border Collateral Arrangements: Summary and Analysis of Draft E.U. Directive on Financial Collateral, 16 (5) J. INT'L BANKING L.119 (2001).

35. Parliament and Council Directive $2002 / 47$ on financial collateral arrangements, O.J. (L 168) 43. On the reasons for EU regulation, see Summe, supra note 17.

36. UNIDROIT, the International Institute for the Unification of Private Law, is "a global legal organization with 59 Member States whose laws include all the key 
garding Intermediated Securities to be adopted by individual nations as international law. ${ }^{37}$ ISDA members aim not only to create substantive legal rights through private contracts, but to influence the shape of those rights as they find expression in state law. ${ }^{38}$

What Wai views as "touchdown points," then, were for my informants, projects-problems that demanded creative work, political mobilization, technical skill, and considerable devotion. What is interesting about typical artifacts of private global governance such as collateral, when viewed in practice, is not whether they are truly private (and outside the purview of the state), or actually public (and within state control), but rather how the impulse, the fantasy of a private market engenders particular kinds of practical projects, particular registers of engagement between lawyers working for private parties under the umbrella of transnational organizations such as ISDA, national and international law-makers, judges, and regulators.

Moreover, the view that private law is just a pass through to state power overlooks the role of the materiality of ISDA forms in the global private governance regime. The rhetorical force of the argument that judges will wreak chaos on the markets if they fail to honor market practices is perhaps different because of the sheer physical ubiquity of these documents. For example, in the early 1990s, the ISDA Master Agreement's procedures for closing out the agreement in the case of the bankruptcy of one party, and its delineation of the rights of the other party in such a scenario, arguably conflicted with the substantive rules and procedures of many national bankruptcy regimes. However, interviews suggest that the widespread use of the Master Agreement-the physical existence of thousands of such signed documents-transformed the question of what to do about substantive legal rules that industry members found unfavorable, a policy question, into a far more general and technical question of the enforceability of this contract in each national jurisdiction.

systems of financial law around the world." UNIDROIT, THE UNIDROIT STUDY Group on Harmonised Substantive Rules Regarding Indirectly Held Securities, POSITION PAPER 5 (2003).

37. The UNIDROIT Secretariat submitted a preliminary draft on December 23, 2004 which was further negotiated by a committee of experts in May, 2005. UNIDROIT, Preliminary Draft Convention on Harmonized Substantive Rules Regarding INTERmediated Securities (2005). See also International Swaps and Derivatives Association, Comment on Preliminary Draft Convention on the Law Applicable to Certain Rights in Respect of Securities Held with an Intermediary (Hague Convention on Private International Law ed., 2002).

38. Anna Gelpern and Mitu Gulati point to a different kind of interaction between standardized contracts and public law: they argue from the case of sovereign debt contracts that standardized contracts can serve as "public symbols"-ways public authorities signal about political events. Anna Gelpern \& G. Mitu Gulati, Public Symbol in Private Contract: A Case Study, 84 WASH. U. L. REv. 1627 (2006). 
The sociological fact that material documents matter admittedly flies in the face of the longstanding assertion that the paper of the contract means nothing in itself, that it is the agreement between the parties, and not the document, that matters. ${ }^{39}$ But commentators have begun to pay attention to the consequences of standardized contracts such as ISDA documents for the authority, legitimacy and power of privatized law in a global market. ${ }^{40}$ Some even celebrate these standardized contracts as examples of "the changing paradigm of international commercial law" towards "privatized law-making."41 And indeed, for ISDA staff and members, collateral documents are crucial technologies of private transnational legal infrastructure-devices through which particular technical, institutional, political, legal, and economic arrangements gain solidity and durability. ${ }^{42}$ This is not to say that judges do not understand that a privately created document is legally meaningful only to the extent that a state-sanctioned court holds it to be enforceable. But what empirical observation of private law in action demonstrates is that in order for the transaction to "work" all sides (parties and judges alike) must be both aware of the "truth" that state power lies behind all private legal regimes and able to momentarily forget this fact to immerse themselves the practical and technical day to day experience of doing private law. ${ }^{43}$

\section{Rethinking Private LaW as a System of Norms}

This brings me to my second target. For proponents and critics of private law alike, global private governance regimes take on the le-

39. See e.g., Stewart Macaulay, Elegant Models, Empirical Pictures and the Complexities of Contract, 11 LAW \& Soc'y REv. 507 (1976-1977); STEWaRT MaCaulay, John Kidwell, William Withford \& Marc Galanter, Contracts: LaW in Action (1995).

40. Schmitthoff long ago identified "the contribution which standard contract forms and general conditions of business... can make to the unification or harmonisation of the law of international trade." Clive M. Schmitthoff, The Unification or Harmonisation of Law by Means of Standard Contracts and General Conditions, 17 INT'L \& CoMP. L. Q. 551 (1968). He emphasized the aura of "realism" about this "unifying activity" owing to the fact that the rules are created by the business community rather than by government. Id. at 555. Ralf Michaels has recently analyzed these issues as a matter of the accommodation of global private law regimes by the state. Michaels usefully dissects these forms of accommodation into three distinct kinds, all of which enter into play in standardized contracts-deference, incorporation, and delegation. Ralf Michaels, The Re-statement of Non-State Law: The State, Conflict of Laws and the Challenge of Global Pluralism, 51 WAYNE L. REv. 1209 (2005).

41. Klaus Peter Berger, The Creeping Codification of the lex Mercatoria (1999).

42. See Bruno Latour, la Fabrique du Droit : Une Ethnographie du Conseil D'ETAT (2002).

43. On this "as if" quality of law, see Hans Vaihinger, The Philosophy of "As If": A System of the Theoretical, Practical and Religious Fictions of Mankind (C.K. Ogden trans., 1925). 
gitimacy of "law" by virtue of the fact that they embody a set of particular norms. ${ }^{44}$ These norms are imagined to be analogous, both in their coercive power and their legitimacy, to the authority of the state, within the purview of the particular community or market sector where they apply.

For the proponents of private law, the rise of private norm-making organizations is a cause for celebration because of the efficiencies and creative regulatory solutions that such private organizations are deemed to provide. There is even an aura of democratization in phrases like "bottom-up lawmaking" used to describe the global production of private law norms. ${ }^{45}$ Implicit in or running alongside this view is often a mild materialist claim that a revolution in information technologies and in the character of capitalism has occurred, resulting in a largely inevitable trend toward the demise of state law-making authority. ${ }^{46}$ But the view of global private law as a regime of norms is equally pervasive among those who critique the delegation of state power to global private authorities. The theorist of globalization Saskia Sassen for example laments that we now face, "a normative transformation in the [sense] of a privatizing of certain capacities for making norms." 47

The notion that communities-in this case communities of global market players-solve their problems and order their behavior by creating norms is a longstanding tenet of functionalist anthropology and one that has had an important shelf life in twentieth century legal scholarship. ${ }^{48}$ In some versions of this dogma, one particularly prevalent in law and society scholarship, social networks serve the same kinds of results as state coercion, and social norms are the prod-

44. Klaus Peter Berger for example writes that business people "create their own law through the drafting, use and refinement of general conditions of trade, standardized contracts and other clauses as well as the development of practices and usages, elevating them from regional to world-wide customs." BERGER, supra note 41, at 2728. In contrast, the fact that these global norms are "spontaneously generated" and not the product of purposeful law-making activity has led one commentator to doubt whether they are coherent enough to constitute a source of law. See Roy Goode, Rule, Practice, and Pragmatism in Transnational Commercial Law, 54 INT'L \& ComP. L. Q. 539, 547 (2005).

45. See Levit, supra note 22.

46. Philip G. Cerny, Embedding Global Financial Markets, in Private OrganizaTIONS IN Global Politics 59 ( Karsten Ronit \& Volker Schneider eds., 2000); David A. Westbrook, City of Gold: An Apology for Global Capitalism in a Time of DisconTENT (2003).

47. Saskia Sassen, De-nationalized State Agendas and Private Norm-Making, in Public Governance in the Age of Globalization 61 (Karl Heinz Ladeur ed., 2004).

48. Most recently, Paul Schiff Berman has called for borrowing once again from the insights of anthropology and cognate fields in the study of globalization to afford "a more nuanced idea of how people actually form affiliations, construct communities, and receive and develop legal norms." Paul S. Berman, From International Law to Law and Globalization, 43 Colum. J. Transnat'L. L. 485, 489 (2005). 
ucts of social networks. ${ }^{49}$ In other versions-ones influenced by Hayekian social thought-the spontaneous quality of norms makes them both more efficient and more just. ${ }^{50}$

The deeper assumption here is that norms and communities are more "real" than the law of the state because they form a context for the law of the state, and context is always more stable and determinate than text. ${ }^{51}$ The socio-legal literature, for example, seeks to demonstrate time and again that the real source of security of contract in the global marketplace is not legal institutions but private networks built on relations of trust among global elites. ${ }^{52}$ To the extent that these regimes are read as systems of private norms, they appear as self evidently more real, more legitimate, more innovative, more complex, closer to the ground, than the state itself.

49. Many political scientists and lawyers see private norms as more "complex" and "heterodox" than state law because each industry makes its own norms and hence the result is a pluralistic legal order with no clear hierarchies of norms. See Cerny, supra note 46, at 60 . In place of national legal systems, these theorists see coexisting, fragmented, sometimes integrated, sometimes conflicting normative orders with different degrees of access to coercive authority-of the state and other coercive forces in society. Boaventura de Sousa Santos, for example, states that "a legal field is a constellation of different legalities (and illegalities) operating in local, national and global time-spaces." Boaventura de Sousa Santos, Toward a New Legal Common Sense: Law, Globalization, and Emancipation 85 (2002).

In a previous project on global public law, I have critiqued this propensity to see networks everywhere and to view these as inherently normatively good. ANNELISE RILES, The Network Inside Out (2000).

50. Robert C. Ellickson, Order Without Law: How Neighbors Settle DisPUTES (1991).

51. See generally RILES, supra note 49.

52. A longstanding insight of the law and society literature is that the mundane activity of "repeat players"-insiders such as the major players in the global private derivatives markets-does not simply comply with, but rather produces, legal regimes. Marc Galanter, Why the "Haves" Come out Ahead: Speculations on the Limits of Legal Change, 9(1) Law \& Soc'y REv. 95 (1974). Edelman, Uggen and Erlanger argue in the context of the regulation of organizations, that "The meaning of law ... unfolds dynamically across organizational, professional, and legal fields." Lauren B. Edelman, Christopher Uggen \& Howard S. Erlanger, The Endogeneity of Legal Regulation: Grievance Procedures as Rational Myth, 105(2) AM. J. Soc. 406 (1999). Specifically, both socio-legal studies and the social studies of finance have emphasized the way social relations can substitute for the impossible demands for information required to effectively police one's agreements in the global marketplace. The argument is that small "clubs" of actors come to know and trust one another intimately, and to develop a rich network of norms governing their transactions, such that very locally defined social relations of trust and informal norms come to substitute for both financial knowledge and legal norms. Mitchel Y. Abolafia, Making Markets: Opportu. Nism and Restraint on Wall Street (1996); Caitlin Zaloom, Out of The Pits: Traders and Technology from Chicago to London (2006). Global legal norms and institutions are created through the efforts of individual legal actors, working on particular projects in the service of their very locally defined interests based upon their social networks-their personal career interests, the interests of their families or class, or of their firms and organizations-to forge alliances with others. Yves Dezalay \& Bryant G. Garth, Dealing in Virtue: International Commercial Arbitration and the Construction of a Transnational Legal Order (1996).. 
From this vantage point, it is easy enough to see why global private governance regimes would seem to pose such a threat to state legitimacy. But does this description of global private law as a collection of norms, and of organizations such as ISDA as norm creators, accurately capture the knowledge work at issue, or does it obscure as much as it reveals? From an empirical perspective, there is something amiss in the descriptions of global private governance as alternative normative communities busy codifying their norms in standardized documents.

In legal terms, collateral is a body of doctrines and theories, a specialized set of property rights. In Tokyo, legal academics, and qualified lawyers working closely with them inside prestigious law firms, read and wrote academic articles about the meaning of the sections of the Civil Code governing collateral relations, and they applied these to collateral in the derivatives markets in legal opinions drafted on behalf of their clients (in particular the foreign banks). Government bureaucrats studied foreign laws, debated law reform projects, drafted new laws, and implemented existing ones.

But as explained above, in the financial markets, one first encounters "collateral" as a mountain of specific pre-printed forms that must be completed and filed before trading can begin, and of confirmation documents that must be exchanged after each trade. What ISDA members, through the battalions of documentation people I studied were busy making were not rules, not norms, not sources of law, but documents.

Legal scholars have read such contracts for their meaning-they have treated them as texts that entextualize particular sets of norms. ${ }^{53}$ But such forms are often meant not to be read, but to be completed. That is, ISDA documents are technologies that compel a very specific kind of activity, form-filling. ${ }^{54}$ ISDA form is a script for a particular kind of collaboration between two parties-the documentation person at Bank $A$ and the documentation person at Bank $B$.

53. Two recent empirical papers present material that hints at trouble for the view of standardized contracts as mere vessels of narrative meaning. Choi and Gulati make the interesting claim that some terms of boilerplate often have no clear meaning even among industry members. Stephen J. Choi \& G. Mitu Gulati, Contract as Statute, 104 MrCH. L. REv. 1129 (2006). Boilerplate does not necessarily enshrine clearly accepted norms, in other words. Unfortunately, rather than push the standardized contracts literature to come to terms with this empirical insight, the authors seek to do away with the trouble this finding causes by proposing a theory of interpretation of these documents that would read industry norms back in. Likewise, Gelpern and Gulati present a fascinating account of how a clause in a standardized sovereign debt contacts came to be changed: despite the extensive work devoted to this change, industry participants insisted that the change mattered little in the end. Gelpern \& Gulati, supra note 38 .

54. Don Brenneis, Reforming Promise, in Documents: Artifacts of Modern KNowledge 41 (Annelise Riles ed., 2006); Hirokazu Miyazaki, Documenting the Present, in Documents: Artifacts of Modern Knowledge 206 (Annelise Riles ed., 2006). 
ISDA documents work as technologies for engaging in a communicative routine. The routine consists of a set of material practices of document production, filing, and exchange-practices that in turn call for further practices, further documents. ${ }^{55}$ In this sense, the document makes possible a set of exchanges defined by the particular kind of knowledge at issue, technical knowledge ${ }^{56}$ that I would like to claim as a form of global private governance. ${ }^{57}$

Crucially, the ISDA form does not presume, as in the socio-legal and private global governance literatures, that documentation people are members of a tight-knit "club," people who know and trust one

55. Annelise Riles, [Deadlines]: Removing the Brackets on Politics in Bureaucratic and Anthropological Analysis, in Documents: ArTifacts of Modern KNowledge 71 (Annelise Riles ed., 2006). In a somewhat analogous way, Karen Knorr-Cetina and Urs Bruegger describe traders' visual experience of the market through the formatting of a computer screen such as the Bloomberg terminal as a kind of "postsocial" form of relationality. Karen Knorr Cetina \& Urs Bruegger, Traders' Engagement with Markets: A Postsocial Relationship, 19(5/6) Theory Culture \& Soc'y 161 (2002). As Mariana Valverde puts it, it demands that we ask "not about the content of claims but about process and flow-about how actors pick through documents or discourses and cobble together new governing machines that recycle old bits in new ways." Mariana Valverde, Authorizing the Production of Urban Moral Order: Appellate Courts and Their Knowledge Games, 39(2) LAw \& Soc'y REv. 419 (2005).

56. How are these deals legally accomplished in the absence of a fully developed framework of global law? The key to this lies in legal work, and the role of legal work in transnational transactions. The term "legal work" is used here to mean technical work, with and on the law, undertaken usually but not necessarily by lawyers, in specific transactions for specific clients.

Doreen McBarnet, Transnational Transactions: Legal Work, Cross-Border Commerce and Global Regulation, in Transnational Legal Processses: Globalisation and Power Disparities 98, 98-99 (Michael Likosky ed., 2002).

57. One of the features of the global private law regime, in the eyes of commentators, is its "technical" quality. That is, the markets at issue are taken themselves to be highly specialized and "of a technical and complex nature." Pedro Gustavo Teixeira, Public Governance and the Co-operative Law of Transnational Markets: The Case of Financial Regulation, in Public Governance in the Age of Globalization 305, 311 (Karl Heinz Ladeur ed., 2004); which accords special power to insiders and professionals:

We find that the ability of professions to exercise lawmaking power in an area such as bankruptcy law increases significantly when agenda setting, inventing and drafting new laws, and legislative politicking takes place underneath the wider horizon of political debate. Politics take place at two levels: when it is above the political horizon, it activates all the forces and counterforces of the political system and thus imports into technical or financial law reform a much wider set of issues than pertain to the substantive and administrative core of the reform itself; this also activates classic patterns of oppositionalism. When it is below the political horizon, it is not widely debated; it does not stir public controversy; it does not activate usual interest group polarities and conflicts; and it does not trigger instinctive party political opposition. Below the horizon, professions can exert much more influence, and they do so characteristically by insisting that their contributions are technical, expert, and neutral and thus do not warrant the scrutiny that might otherwise focus upon them.

Bruce G. Carruthers \& Terence C. Halliday, Professionals in Systemic Reform of Bankruptcy Law: The 1978 U.S. Bankruptcy Code and the English Insolvency Act 1986, 74 AM. BANKR. L. J. 35, 74 (2000). 
another. ${ }^{58}$ The documentation people I worked with did not belong to any such "club"-their counterparties were simply anonymous voices on the other end of a telephone, or people on the other end of the fax or e-mail. ${ }^{59}$ This routine is made possible not by a set of shared norms, but by a given set of aesthetic criteria - printed forms are distinguished from other genres of communication such as letters, legal opinions, or e-mail messages by their very rigid aesthetic standards. ${ }^{60}$ These aesthetic criteria in turn demand that the users of the forms engage in very specific forms of behavior: one chooses the law that applies to the ISDA master agreement by circling the proper word; one delineates who is the responsible contact person for the agreement by completing the relevant box. The form is not set out to be read; it is presumed that the "users" (the term is significant) will jump to the blanks and complete them, most likely in the order they appear. The collaboration made possible by the printed form is certainly consequential, in other words, but it is also normatively and socially thin. ${ }^{61}$ In other words, "collateral" is not just an artifact of private networks and associated normative communities but a technology, and a technical form of agency, of its own.

Many law and society scholars will insist that the claim that the law functions independently of social context is nothing but a phantasmic assertion or worse, a political obfuscation. ${ }^{62}$ My own first entrée into the larger significance of collateral for a theory of legal knowledge came from what I took to be just such obfuscation: my informants' manifest lack of interest in the subject of disputes. As a legal anthropologist, I am predisposed to take an interest in disputes and cultures of disputing, and so I naturally peppered my informants with questions about how disputes among counterparties over the terms of a swap get resolved. Given the notional amounts at stake, I reasoned that these disputes must occupy considerable effort and energy. To my dismay, however, these questions elicited little interest on the part of the documentation people I knew. "We just work these things out," I was told again and again, with a standard shrug, before people turned the conversation back to subjects of greater concern to them. When, confident that people were hiding something, I pointed

58. See Levit, supra note 22 , at 131.

59. One could say that the users of ISDA forms share a set of institutional practices, codes of behavior, by virtue of the fact of their employment in particular kinds of institutions (e.g., banks and securities firms). But this simply restates the argument here: ISDA forms are one important material instantiation of this institutional practice.

60. Annelise Riles, Introduction: In Response, in Documents: Artifacts of ModERN KNOWLEDGE 1 (Annelise Riles ed., 2006).

61. See also Niklas Luhmann, A Sociological Theory of Law (Elizabeth King \& Martin Albrow trans., 1985).

62. Susan Silbey has produced a detailed critical retrospective of this argument. Susan Silbey, After Legal Consciousness, 1 ANN. Rev. L. \& Soc. ScIEnce 323 (2005). 
out that the ISDA CSA documents provide for a quite elaborate set of procedures to be followed in the event of a dispute, people laughed. No one actually followed those procedures, I was told. Rather, people tended to have in mind a range within which, should a dispute arise, they would simply go along and not contest. If the disputed amount was outside that range, they would simply come to some agreement, usually by splitting the difference. At one point, one informant told me, it was suggested that a more formal dispute resolution mechanism should be set up, but the idea was abandoned because "nobody wanted to serve on it." There are also remarkably few examples of formal litigation among swap parties.

To grasp the theoretical significance of this fact, compare collateral with a favorite subject in the theory of global private law, international commercial arbitration. Arbitration is theoretically interesting for socio-legal scholars because we can see in it private actors banding together, elaborating their own dispute resolution system, developing over time their own body of adjudicative norms, and increasingly, garnering state approval for these norms. That is, arbitration is interesting in a somewhat obvious way, because it is quite explicitly an analog to state law, an alternative to state law with all of state law's functional elements-a regime of norms, a set of procedures, a set of problems (disputes). But collateral works according to a quite different logic. In theory at least, if a transaction is collateralized, there is no need for dispute resolution in the first place. The dispute is already resolved, already collateralized, so to speak, before it ever comes into existence. And just because things do not turn out so neatly in practice does not mean that we should ignore the fantasy, the ambition, the hope of collateral.

From this point of view, we might view collateral arrangements as a form of law that aims to be both the obviation of dispute resolution as well as its apotheosis. Indeed, collateral is difficult to be seen as a "topic" of legal theory precisely because its modus operandi is not at all alternative and analogous to standard law, with its disputes resolved according to norms enshrined in legal processes.

If this point is difficult to accept from a socio-legal point of view in which law is always a (less legitimate) artifact of (more authentic) social relations, it is, I think, very much part of the lawyer's common sense understanding of the law. In practitioners' own ideology, collateral is as a way of setting limits on the messy complexities of a global market, a way of obviating the need for knowledge and trust, an alternative to developing shared private norms. One could say that in fact collateral is the precise opposite of social norms. That is, collateral aspires to make it possible for global actors to deal with one another without trust, without shared norms, without a thick web of 
personal relations or an elaborate alternative system of dispute resolution.

\section{Rethinking the View of Transnational Private Law as a Coherent or Standardized System}

I have argued thus far that critiques of global private law as an artifact of state power miss the extent to which that the interface between private authority and state power is itself the very basis for the flurry of activity that is global private law, from an empirical vantage point. And on the other side of the ledger, I have argued that utopic and dystopic accounts of global private law that see in it a spontaneous and more legitimate set of norms fail to account for the fact that private law is not just a set of norms but a set of knowledge practices. I now want to take on one last source of global private law's legitimacy, the question of its coherence-analytical or sociological. This brings us to a conversation about practices of standardization.

The standardized quality of law-making has recently captured the attention of law and economics and law and society scholars alike. Where law and economics scholars see cost savings, ${ }^{63}$ socio-legal scholars see the production of new legal regimes through the routinization of work and professional roles. ${ }^{64}$ Standardization is also a central concern of science and technology studies scholars for whom standards produce epistemic networks-collections of projects, associated ideas and technologies for working on them, and ultimately, the "truths" that emerge from these. 65

63. A core insight of the law and economics literature on standardized contracts is that standardization serves the important economic function of reducing the transaction costs associated with producing new contracts, such as researching the law and drafting the terms of the contract ("learning benefits"). Marcel Kahan \& Michael Klausner, Standardization and Innovation in Corporate Contracting (or "The Economics of Boilerplate"), 83 VA. L. REv. 713, 719-20 (1997). For example, Kahan and Klausner point out that standardized contracts also reduce litigation costs because they deploy terms that have already been vetted in court. Id.

64. For example, Mark Suchman, working in the domestic American context of the development of intellectual property law in Silicon Valley, draws attention to mundane practices of contract production as one source, among others, of the creation of new legal norms. Suchman points to "a significant but often overlooked aspect of industrial governance: the routinization of transactional practices within a developing organizational community." Mark Suchman, The Contracting Universe: Law Firms and the Evolution of Venture Capital Financing in Silicon Valley 2 (2007) (unpublished manuscript, on file with the author). Likewise, Doreen McBarnet and Michael Powell argue, for the case of international tax lawyers and corporate takeover law respectively, that law is the artifact of the accumulation of individual legal projects and of solutions developed by lawyers operating separately in the service of their clients. See Doreen McBarnet, Legal Creativity: Law, Capital and Legal Avoidance, in Lawyers in a Postmodern World: Translation and Transgression 73 (Maureen E. Cain \& Christine B. Harrington eds., 1994); McBarnet, supra note ; Michael J. Powell, Professional Innovation - Corporate Lawyers And Private Lawmaking, 18 (3) LAW \& Soc. INQUIRY 423 (1993).

65. Science studies scholars have argued that scientific truths and economic markets are artifacts of networks of theories, ideas, people, institutions, machines, and 
Built into all of these arguments is the notion of a network of actors who share certain abilities to signal to one another and to learn from one another. ${ }^{66}$ In this sense, the standardization vocabulary is a richer and more empirical way of arguing for what legal scholars used to call the coherence of law. By discovering networks of material and conceptual kinds, scholars are able to show that the "stuff" of documents, of doctrine, of mundane legal knowledge actually "adds up" to a larger whole, something of much greater significance. A document gains theoretical significance by virtue of its status as a node in a larger standardized network of forms of expertise. A network in turn gains theoretical significance by virtue of its status as the accumulation of concrete practices, all related into a whole. ${ }^{67}$

This vision of the world not as a system of states but as a myriad networks-whether these be networks of economic actors or networks of doctrines and documents-is an attractive argument for the legitimacy and authority of private law beyond the state. ${ }^{68}$ But does the claim that the disparate and mundane bits of legal knowledge add up to a new kind of whole do justice to the perspective of the actors themselves? Where the theorists may see connections everywhere, the actors involved are just as likely to see breaks, divides, a lack of connections. To take their perspective seriously is to ponder the ways often nothing in particular is being "constructed" by these practicesthe way they do not add up to a coherent whole.

First, as any comparative lawyer would immediately understand, the standardization of ISDA documents did not in any way guarantee their transnational transplantability. ${ }^{69}$ Rather, the trans-

other "actants"-nodes of animate and inanimate agency. See Bruno LATOUR, ScI. ence in Action: How to Follow Scientists and Engineers Through Society (1987); Aramis or, The Love of Technology (1996). More recently, Latour has extended the analysis to law in his study of the French Conseil d'Etat. See Latour, supra note 42. Documents in this understanding are "immutable, presentable, readable and combinable" artifacts used to mobilize networks of ideas, persons, and technologies. Bruno Latour, Drawing Things Together, in REPRESENTATION IN SCIENTIFIC Practice 26 (Michael Lynch \& Stephen Woolgar eds., 1988).

66. The legal literature on standardized contracts, for example, emphasizes that standardized contracts facilitate "coordination" among the parties by focusing attention on certain "focal points" and allowing the parties to treat others as settled. Robert B. Ahdieh, The Strategy of Boilerplate, 104 Mich. L. REv. 1033 (2006); Choi \& Gulati, supra note 53. There are "network benefits" to standardized contracts whereby the more parties use the contracts, the more standard they become and hence more valuable they become to all users. See Kahan \& Klausner, supra note 63, at 725 .

67. The intuitive aesthetic appeal of this argument has much to do with a wider modernist aesthetic of relationality. I have critiqued the aesthetics of networks in an earlier monograph. See RILES, supra note 49.

68. See Keck \& SikкINK, supra note 5; Kathryn Sikkink, Human Rights, Principled Issue-Networks, and Sovereignty in Latin America, 47 (3) INT'L ORG. 411 (1993); Anne-Marie Slaughter, The Real New World Order, 76 (5) Foneign AfF. 183 (1997).

69. See alan Watson, Legal Transplants: An Approach to Comparative law (2d ed., 1993). 
latability of these documents required the work of particular experts, the documentation people. The institutional venue for the transplantation of this foreign legal regime to the Japanese market were the meetings of a "documentation committee" of back-office staff from various Japanese and foreign banks sponsored by ISDA Tokyo. At these meetings, back office staff discussed the details of form filling with an aim to "standardize" and "create protocols" for form-filling, where the terms of the forms laden with assumptions about market practices in the American and British markets raised problems or made nonsensical assumptions in the context of the Japanese market. For example, the New York documents prescribed that collateral should be transferred within three days, as was the practice in New York, but at the time, neither the Japanese banks nor the clearing system for Japanese Government Bonds maintained by the Bank of Japan was sophisticated enough to achieve this. From documentation people's point of view, the discontinuities between the bits and pieces of the global network were as apparent and salient as the connections.

Likewise, commentators on private law have repeatedly commented on its scholastic quality and of the break between theory and practice this scholasticism necessarily implies. ${ }^{70}$ As an empirical matter this break between the scholastic and private law worlds was a central effect of the package of doctrines and documents that made up collateral. Expertise consisted of two sides. Some experts, the "more academic," prototypically, university professors, made theories. Others, "the practicing lawyers," completed documents. The documents and theories generated a bifurcated legal field-a field characterized by divisions of status and expertise rather than networked connections.

Moreover, to flatten out the distinction between theory and practice, and to see practical legal work as simply an instantiation of legal theory and doctrine, that is, to see legal theorists and legal practitioners as working with one coherent network of legal concepts, overlooks the important practical work done by the distinction between theory and material document in actual legal practice. Let me give one concrete example of what I mean. Sometimes filling in the collateral forms presented what my informants described as "difficult problems." Swap trading partners-foreign swap partners-wished to have extensive rights concerning the collateral of Japanese banks they held. ${ }^{71}$ They wanted to be able to sell the collateral to a third party, or again to use it as collateral of their own in future swap

70. See. e.g., James Gordley, Foundations of Private Law: Property, Tort, CONTRACT, UNJUST ENRICHMENT 5, 41 (2006).

71. International Swaps and Derivatives Association, Collateral Survey 105 (2000); Paul Avanzato, How to Use the Collateral Carousel, 17 (1) INT'L FIN. L. REv. 2 (1998). 
transactions. ${ }^{72}$ And these "difficult problems" raised further questions of theory and doctrine. American and UK law allowed for this so-called rehypothecation, but the law of Japan provided that the holder of collateral had certain duties of care and hence could not alienate the collateral without the permission of the party that had initially posted it. ${ }^{73}$ One threshold legal question therefore was what country's law would govern the rights over collateral posted by a Japanese bank with an American bank, for example-Japanese or American law. ${ }^{74}$

The full answer to this legal question involves complex and murky jurisprudential and even epistemological issues (what law should govern a transaction between a Japanese and UK bank, posted to their subsidiaries in the Cayman Islands, involving a swap of Chinese currency for Singaporean currency? And given that in most legal systems the law traditionally attempts to answer such questions in territorial terms, where did the transaction take place? Where is the collateral, some numbers in some accounts, "held"?) But the lawyers at ISDA headquarters in New York had prescribed a simple solution grounded not in legal theory but in concrete practices of documentation. These lawyers had produced a "collateral annex"75 to the ISDA Master Agreement which included, among other things, a clause specifying that the parties agreed in advance that all disputes over collateral should be governed by either UK or New York law. The form simply required documentation people to circle "law of New York" or "law of the United Kingdom," to initial the document signaling their assent, and to file it. ${ }^{76}$ In other words, the perception of a

72. Christian A. Johnson, Derivatives and Rehypothecation Failure - It's 3:00 p.m., Do you know where your collateral is?, 39 ARIz. L. REv. 949 (1997); Bill Mapother, Get Double Duty from Collateral, 64(2) CREDIT Union Magazine 74 (1998).

73. 担保契約における消費贷借構成とようしんの捉え方について (tanpo keiyaku ni okeru shouhitaishaku kousei to youshin no toraekata ni tsuite. A Method for understanding Pledges based on Loan and Set-off [Loan for Consumption, Return of the Same Kind]).

74. See Guynn, supra note 27.

75. See ISDA Collateral Documentation Working Group, supra note 13; International Swaps and Derivatives Association, Inc., Guidelines for Collateral Practitioners (1998); David Suetens, Collateralization and the ISDA Credit Support Annex, 14 (8) INT 'L Fin. L. Rev. 15 (1995).

76. ISDA has attempted to address the private international law issues surrounding collateral by creating versions of its collateral agreement that are specifically tailored to the laws of the UK, New York, and Japan. In each of these versions, the parties expressly affirm that they wish the law of the UK, New York or Japan to apply to their transaction. In so doing, they rely upon a doctrine of private international law that in matters of contract, the parties should be able to choose which law applies to their transaction so long as it bears a reasonable relationship to the transaction. EuGene F. Scoles et al., Conflict of Laws 947 (3d ed. 2004). In Japanese law, this principle is codified in the statute; Horei [Application of Laws General Act], Law No. 10 of 1898, art. 7(1), as amended: "As regards the formation and effect of a juristic act, the question as to the law of which country is to govern shall be determined by the intention of the parties.". 
difference between a document and a theory-even if all would agree at another level of argument that the document is just an instantiation of a theory-"cut the network"77 of legal theorizing. Sometimes crude commonsense distinctions between the ontological status of theories and objects have their practical uses. In this case, it provided a way out of doctrinal debates which ISDA lawyers understood to be endless.

From a broader theoretical vantage point, we could say much of the same about the relationship between law and other forms of expertise in the financial markets. It is common in Weberian and science studies inspired work on markets to think about law as a form of technocratic expertise, alongside economics. In this understanding, lawyers are experts because they have access to a specialized body of knowledge that allows them to make connections and serve as brokers of various kinds. The science studies literature emphasizes the way disparate forms of expertise (such as law and finance) are able to come together through material technologies such as documents that translate between them. But this picture of smooth translatability and collaboration between law and finance does not sit well with the experience of the documentation people I knew. One of the features of the work of the documentation people was that it locked them into a relationship with a set of concepts, machines and persons which they were acutely aware they did not understand-into a relationship premised on a lack of knowledge. As lawyers, they were intensely aware that they did not understand the mathematical details of collateral valuation, for example, nor did they understand the humans and machines that performed these calculations. And yet the work of documentation depended in concrete and ubiquitous ways on valuation. And in fact this disconnect between traders and lawyers (later mandated by financial regulators who insisted, as part of market reforms, that lawyers be physically moved to a different space, the "back office" where they might be even more independent from traders) was precisely their added value within the institution. Part of what rendered the documentation people experts was their lack of knowledge of certain aspects of the financial markets. I believe this is an observation that has some generalizability: in a global market in which information overload is the taken for granted starting point, it is easy to see how value is attributed to a practice that steps back, that makes the picture simple by shutting out all the detail. ${ }^{78}$ The market value of private law, we might say, resides not so much in its ability

77. Marilyn Strathern, Cutting the Network, 2(3) J. Royal ANTHROPOLOGY INST. 517 (1996).

78. This is what makes legal knowledge technocratic in my view, for bureaucratic work also begins from the premise of a certain lack of local knowledge. DocumENTs: ARTIFACts OF MOdERN KNowledge (Annelise Riles ed., 2006). 
to be networked with other forms of expertise as in its propensity to cut itself off, to compartmentalize problems.

In place of networks of people, institutions, objects, experts, and ideas that create coherent standards, new forms of transparency, communities of expertise, and truths, one coherent doctrinal or sociological whole, then, we have pockets of lack of knowledge, breaks between theory and practice, genres of opacity, differences in ontological status, lack of understanding of the agency and expertise of others. We have a flurry of activity that creates distinctions, sets limits, cuts one genre of thought and one line of analysis from another, activity that is not building anything in particular, that does not "add up" to a new legal regime, or a new market sphere, or a new source of epistemological or juridical authority. I call this "private law as Anti-Network" to distinguish it from the range of pictures of private law that focus on networks and connections of one kind or another.

\section{The Anti-Network AND the State}

This brings me to the mutually derived legitimacy of private law and the state. Most theorists of global private governance focus on the emergence of a new set of parallel norms, customs, and rules, or a new set of social relations, institutions and practices, outside the purview of the state, as a threat to the legitimacy of the state. But as we saw, collateral is something quite distinct from a set of customs and norms. It is a device for privately making the very need for norms go away: global actors seek to take their disputes out of the hands of national regulation and dispose of them before they ever come to be.

Ironically, there are certain parallels here with the knowledge practices that constitute the state. The state is not just the expression of a set of political norms, nor is it just the institutionalization of a set of communities, networked or otherwise. Neither is it a coherent system. Rather, the practice of making distinctions, compartmentalizing, cutting off and setting limits is an exercise in creating and manipulating legitimacy that has also long been one of the privileges, and the contributions, the knowledge practices of the state. This is what we mean by bureaucratization and proceduralism, the hallmarks of the modern state-a set of scripts or routines for cutting off, compartmentalizing, and hence channeling politics. Viewed from this perspective, global private law is not a radical departure from state law, but really more of the same.

The question of the legitimacy of both private law and the state is usually addressed at a theoretical or political level of analysis, but the above point suggests that it is worth addressing it at a very mundane techno-sociological level as well. That is, we may wish to think of the production of legitimacy as a set of technical practices of com- 
munication and associated expectations. ${ }^{79}$ For example, the materiality of ISDA forms, discussed above, plays a concrete role in the private quality of collateral as a regime of global private governance. Collateral then is a set of material and theoretical knowledge practices, a documentary regime that compels certain forms of legal collaboration according to carefully scripted routines, and that in turn creates certain specific kinds of legitimacy.

The larger point I wish to make is this: the "threat" of private law devices such as collateral to the state, if any, inheres in the way they appropriate and redeploy the very knowledge practices that characterize the modern state, not in the way they appeal to norms outside or beyond these. We have then a condition in which the state is not so much challenged as mirrored, reflected, and deflected in new technical forms.

79. See LuhmanN, supra note 61 , at 200 . 